\title{
DETERMINATION OF TOTAL PROTEIN IN SPINAL FLUID WITH SULPHOSALICYLIC ACID AND TRICHLOROACETIC ACID
}

\author{
O. MEULEMANS \\ With the technical assistance of Miss E. G. VergeER \\ Department of Pediatrics, State University, Utrecht (The Netherlands)
}

(Received January I6th, 1960)

Amongst the methods for the determination of total protein in spinal fluid, that involving a $3 \%$ sulphosalicylic acid solution is commonly used owing to its simplicity and rapidity. There exists, however, a great discrepancy between the total protein found in an artificial albumin and globulin mixture when the biuret and the sulphosalicylic acid methods are compared. The sulphosalicylic acid gives much higher values than the biuret method.

\section{SULPHOSALICYLIC ACID}

In 1939 LOONEY AND WALSH ${ }^{1}$ criticized different methods for the estimation of spinal fluid proteins, and found most of them far from satisfactory. They stabilized the turbidity of the protein precipitate with sulphosalicylic acid (SSA), by means of a solution of gum ghatti; the turbidity was constant up to 30 hours after mixing. The calibration curve however, does not follow Beer's law. The slight opalescence of the gum ghatti solution has also an influence and must be taken into account.

SCHNEIDER ${ }^{2}$ thinks SSA unsuitable for the determination of protein and prefers the use of ammonium sulphate. CARTIER AND PICARD ${ }^{3}$ consider that SSA is a specific reagent for proteins. At lower concentrations SSA precipitates only proteins and the intensity of the absorbance depends not only on the protein concentration but also on the volume of the precipitated molecules. Solutions of different proteins will therefore give different absorbances even when the weight ratios are equal. SSA precipitates many heterocyclic substances and this discourages the use of SSA as a precipitating agent.

\section{Method}

In our experiments electrophoretically pure albumin and globulin were used. Solutions of $7.4 \%$ albumin and of $8.3 \%$ globulin were diluted a hundred times with water. The turbidity formed by mixing $4 \mathrm{ml}$ of SSA $(3 \%)$ and I ml of the diluted protein was measured at $450 \mathrm{~m} \mu$ in the Beckman B spectrophotometer. In Table I the results are given.

In the $5^{\text {th }}$ and $7^{\text {th }}$ column the optical densities of a $I \%$ protein solution are derived from the total protein $P$ and the optical density $E$, thus $\mathrm{I} \% O . D .=P / E$. (column 4/column 3) If the O.D.'s are a linear function of the protein concentration, the $I \% O . D$. values are constant. As will be seen from the table, this is not true in column 5. Pure albumin has a higher $1 \%$ O.D. than has pure globulin. This is the 
reason why a $3 \%$ SSA solution is unsuitable for the determination of total protein in spinal fluid. According to BooY ${ }^{4}$, the spinal fluid contains $53 \%$ of albumin and $47 \%$ globulins. The use of a $3 \% \mathrm{SSA}$ solution therefore gives too high results.

\section{Mixtures of sulphosalicylic acid and sodium sulphate}

In qualitative urine analysis, a mixture of SSA and sodium sulphate is used for the detection of protein in urine (Exton Reagent). Analogously, the effect of sodium sulphate on the determination of protein with SSA in spinal fluid was studied. When

TABLE I

OPTICAL DENSITIES OF PURE ALBUMIN AND GLOBULIN MIXTURES

\begin{tabular}{ccccccc}
$\begin{array}{c}\text { Albumin } \\
\text { parts }\end{array}$ & $\begin{array}{c}\text { Globulin } \\
\text { parts }\end{array}$ & $\begin{array}{c}\text { Total } \\
\text { protein } \%\end{array}$ & \multicolumn{2}{c}{$S S A(3 \%)$} & \multicolumn{2}{c}{$S S A(3 \%)$ and $\mathrm{Na}_{2} S \mathrm{~S}_{4}(7 \%)$} \\
\hline IO & - & 7.40 & O.D. & $I \% O . D$ & $O . D$. & $I \%$ O.D. \\
8 & 2 & 7.58 & 0.824 & 0.155 & 0.434 & 0.059 \\
6 & 4 & 7.76 & 0.658 & 0.109 & 0.454 & 0.060 \\
4 & 6 & 7.94 & 0.635 & 0.080 & $0.47 \mathrm{I}$ & $0.06 \mathrm{I}$ \\
2 & 8 & 8.12 & 0.599 & 0.074 & 0.523 & 0.063 \\
- & IO & 8.30 & 0.565 & 0.068 & $0.55^{\circ}$ & 0.066 \\
\hline
\end{tabular}

TABLE II

INFLUENCE OF ADDED SODIUM SULPHATE TO SULPHOSALICYLIC ACID

\begin{tabular}{|c|c|c|c|c|c|c|}
\hline \multirow{2}{*}{$\begin{array}{l}\% \text { Sodium sulphate } \\
\text { added to } 3 \% \text { sulpho- } \\
\text { salicylic acid }\end{array}$} & \multicolumn{2}{|c|}{$\begin{array}{l}4.4 \% \text { Albumin sol. } \\
\text { (dil. Ioo times) }\end{array}$} & \multicolumn{2}{|c|}{$\begin{array}{c}4.3 \% \text { Globulin sol. } \\
\text { (dil. 100 times) }\end{array}$} & \multicolumn{2}{|c|}{$\begin{array}{c}\text { Alb. }(80 \%) \& \text { Glob. }(20 \%) \\
\text { mixture } \\
\text { (dil. Ioo times })\end{array}$} \\
\hline & $O . D$. & $I \% O . D$ & $O . D$. & $I \% O . D$ & $O . D$ & $I \% O . D$. \\
\hline o & 0.824 & 0.187 & 0.256 & 0.059 & 0.569 & 0.129 \\
\hline I & $0.65^{2}$ & $0.14^{8}$ & 0.256 & 0.059 & $0.45^{8}$ & $0.10_{4}$ \\
\hline 3 & 0.444 & 0.101 & $0.27^{2}$ & 0.063 & 0.377 & 0.086 \\
\hline 5 & 0.347 & 0.079 & 0.284 & 0.066 & 0.319 & 0.073 \\
\hline 7 & 0.284 & 0.067 & 0.276 & 0.064 & 0.276 & 0.063 \\
\hline
\end{tabular}

different amounts of sodium sulphate were mixed with a $3 \%$ SSA solution, the I $\%$ O.D. of pure albumin solutions (diluted roo times with distilled water) were lowered, as can be seen from Table II.

From Table II the following conclusions can be drawn. (I) Globulin has an almost constant $1 \%$ O.D. in 3\% SSA and in mixtures of SSA and sodium sulphate. (2) Globulin as well as sodium sulphate have a lowering effect on the optical density of albumin. (3) The I \% optical densities of albumin, globulin and mixtures of albumin and globulin are the same at a concentration of $7 \%$ sodium sulphate in $3 \%$ SSA.

Thus a solution of $3 \%$ SSA containing $7 \%$ sodium sulphate should be used for the determination of total protein in spinal fluid, instead of a $3 \%$ SSA solution. This mixture gives protein values which are more in agreement with the true protein value in cerebrospinal fluid than a $3 \%$ SSA solution.

\section{Method}

Reagents. (a) $6 \mathrm{~g}$ of SSA are dissolved in roo $\mathrm{ml}$ distilled water. (b) $\mathrm{I} 4 \mathrm{~g}$ of anhy- 
drous sodium sulphate are dissolved in $100 \mathrm{ml}$ water. A mixture of equal volumes of a and $\mathrm{b}$ is used for the protein determination (SSA-SS mixture).

Procedure. To $\mathrm{Iml}$ of cerebrospinal fluid is added $4 \mathrm{ml}$ of the above mixture. After ro min the optical density is read in the spectrophotometer at $450 \mathrm{~m} \mu$. The O.D. multiplied by a factor $f$ is the protein content (see below).

\section{The standard curve}

By means of different diluted sera with known protein content (biuret reaction) the mean $I \%$ O.D. and the standard deviation can be determined. The standard curve, i.e. the best fitting straight line, goes through the origin and this value. $3 \mathrm{~T}$ different sera gave a mean I\% O.D. of $0.065^{8}$ and a S.D. of 0.0045 . The accuracy of the method

TABLE III

COMPARISON OF THE SULPHOSALICYLIC ACID METHOD WITH OTHER METHODS

\begin{tabular}{|c|c|c|c|c|c|c|c|}
\hline & Methods & $\begin{array}{c}\text { Sym- } \\
\text { bol }\end{array}$ & $\begin{array}{c}\text { Number } \\
\text { of } \\
\text { determi- } \\
\text { nations }\end{array}$ & $\begin{array}{l}\text { Sans- } \\
\text { pies }\end{array}$ & Regression equations & $\begin{array}{c}\text { Cortala- } \\
\text { tion } \\
\text { coef } \\
r\end{array}$ & $\begin{array}{c}\text { Standarat } \\
\text { errors } \\
\text { of estimate }\end{array}$ \\
\hline A & $\begin{array}{l}\text { Sulphosalicylic acid }(3 \%) \\
\text { SSA-SS }\end{array}$ & $\begin{array}{l}\mathrm{Y} \\
\mathrm{X}\end{array}$ & 35 & $\operatorname{CSF}$ & $\begin{array}{l}Y=\mathbf{1}, 26 X-1.0 \\
X=0.75 Y+3.1\end{array}$ & 0.97 & $\begin{array}{l}S_{y}=5 \cdot 7 \\
S_{x}=4.4\end{array}$ \\
\hline B & $\begin{array}{l}\text { Kafka } \\
\text { SSA-SS }\end{array}$ & $\begin{array}{l}\mathbf{Y} \\
\mathbf{X}\end{array}$ & 27 & $\operatorname{csF}$ & $\begin{aligned} Y & =0.7 \times X+12.7 \\
X & =1.04 Y-2.4\end{aligned}$ & 0.80 & $\begin{array}{l}S_{y}=6.2 \\
S_{x}=8.1\end{array}$ \\
\hline C & $\begin{array}{l}\text { Sulphosalicylic acid }(3 \%) \\
\text { Kafka }\end{array}$ & $\underset{\mathrm{X}}{\mathrm{Y}}$ & 30 & $\mathrm{CSF}$ & $\begin{array}{l}Y=1.6 X-16.2 \\
X=0.51 Y+16.1\end{array}$ & 0.90 & $\begin{array}{l}S_{y}=9.77 \\
S_{x}=5.5\end{array}$ \\
\hline
\end{tabular}

at these low protein concentrations, is therefore $7 \%$. The multiplication factor to convert the optical densities into $\mathrm{mg} \%$ is $\mathrm{I} / 0.0658=\mathrm{I5} .2$ (see Procedure).

\section{Comparison of the SSA and the SSA-SS method (Table III,A)}

There is a high degree of correlation $(r=0.97)$. From the regression equations it is clear that the SSA method gives higher values than the SSA-SS method. The albumin fraction is responsible for these higher values by the SSA method. In $95 \%$ of the cases the actual values lie within \pm 2 standard errors of estimate of the regression equation line.

The high degree of correlation denotes that the SSA-SS method is as good as the SSA method for the estimation of total protein in cerebrospinal fuid. The only difference is the exclusion of the albumin interference in the SSA-SS method.

\section{The SSA-SS method compayed with the Kafka method (Table III,B)}

The correlation is high $(r=0.86)$ and the regression equations have parameters of slope which approach unity. The SSA-SS method is thus similar to the Kafka method, but has the advantage of speed. The results of both methods are the same.

\section{Comparison of the SSA method with the Kafka method}

A comparison reveals a high correlation coefficient $(r=0.90)$ and high values for the SSA method. This follows from the parameters of slope of the regression equations (Table III, C). 
From the above it can be concluded that $(I)$ The SSA method gives high results. (2) The SSA-SS method is in good agreement with the true protein values in cerebrospinal fluid. (3) The SSA-SS and the Kafka methods are equally good. (4) The SSA-SS is a very simple and rapid procedure.

\section{TRICHLOROACETIC ACID}

For deproteinisation of body fluids trichloroacetic acid (TCA) is a well known agent in the clinical laboratory. For the quantitative determination of total protein however, this acid has not been used. DEBro et al ${ }^{5}$ worked out a method involving TCA for the separate determination of albumin and globulin. The authors use a $\mathrm{I} \%$

TABLE IV

COMPARISON OF THE TRICHLOROACETIC ACID METHOD WITH OTHER METHODS

\begin{tabular}{|c|c|c|c|c|c|c|c|}
\hline & Methods & $\begin{array}{l}\text { Sym- } \\
\text { bol }\end{array}$ & $\begin{array}{c}\text { Number } \\
\text { of } \\
\text { determi- } \\
\text { nations }\end{array}$ & Samples & Regression equations & $\begin{array}{c}\text { Correla- } \\
\text { tion } \\
\text { coeff. } \\
r\end{array}$ & $\begin{array}{l}\text { Standa } \\
\text { error } \\
\text { of estim } \\
S_{y}\end{array}$ \\
\hline $\mathrm{D}$ & $\begin{array}{l}\text { Sulphosalicylic acid }(3 \%) \\
\text { Trichloroacetic acid }(3 \%)\end{array}$ & $\begin{array}{l}\mathrm{Y} \\
\mathrm{X}\end{array}$ & 21 & $\operatorname{CSF}$ & $\begin{array}{l}Y=1.26 X-0.3 \\
X=0.2 Y+32\end{array}$ & 0.50 & $33 \cdot 2$ \\
\hline$E$ & $\begin{array}{l}\text { Kafka } \\
\text { Trichloroacetic acid }(3 \%)\end{array}$ & $\begin{array}{l}\mathbf{Y} \\
\mathbf{X}\end{array}$ & 18 & CSF & $\begin{array}{l}Y=0.68 X+12.2 \\
X=0.99 Y+0.8\end{array}$ & 0.82 & $4 \cdot 7$ \\
\hline$F$ & $\begin{array}{l}\text { SSA-SS } \\
\text { Trichloroacetic acid }(3 \%)\end{array}$ & $\begin{array}{l}Y \\
X\end{array}$ & 20 & $\mathrm{CSF}$ & $\begin{array}{l}Y=1.03 X-1.0 \\
X=0.95 Y+1.9\end{array}$ & 0.99 & 2.2 \\
\hline
\end{tabular}

TCA solution in ethyl alcohol to separate albumin from the globulins, an observation first made by Delaville $e t$ al. ${ }^{6}$.

An attempt has been made to use a TCA solution as the sole reagent for the determination of total protein of spinal fluid. From preliminary experiments, a $3 \%$ TCA solution in distilled water was chosen as the reagent, because this proved to be the minimum TCA concentration that gives the same extinctions for pure albumin and globulin solutions of the same concentration. The behaviour of albumin and globulins is thus the same when TCA is used as a reagent in contrast to their behaviour with a $3 \%$ SSA solution.

\section{Procedure}

Mix I ml of spinal fluid with $4 \mathrm{ml} 3 \%$ TCA in water, and read the optical density at $450 \mathrm{~m} \mu$ in the spectrophotometer Io min after mixing. Remix again before reading the O.D. The conversion factor for O.D. into $\mathrm{mg} \%$ of protein can be estimated by diluting a standard serum of known protein content and treating it in the same way.

\section{Comparison of the TCA method and the SSA method (Table IV,D)}

From the bad correlation $\left(r=0.5^{\circ}\right)$ and the regression equations it can be concluded that these two methods are different. As in the case of the SSA-SS method, the protein values of the TCA method are lower than those of the SSA-method. 


\section{Comparison of the TCA method and the Kafka method (Table IV, E)}

The correlation is high $(r=0.82)$ and the regression lines nearly overlap each other. The methods are therefore similar.

\section{Comparison of the SSA-SS method with the TCA method (Table IV, F)}

A correlation coefficient of $r=0.99$ and the overlapping regression lines with slopes of practically $45^{\circ}$ show that these methods give the same results. The conclusion can be drawn that there is no difference between the SSA-SS or the TCA method

The fact that only one reagent is required with the TCA method tends to make this the method of preference.

\section{ACKNOWLEDGEMENT}

We wish to thank Miss C. van Coolwijk of the Military Hospital, Utrecht, for her kind cooperation in the Kafka method determinations and in helping with the spinal fluid which we needed for this investigation.

\section{SUMMARY}

The commonly used $3 \%$ sulphosalicylic acid method for the determination of protein in spinal fluid does not give satisfactory results, and two other methods are described. The first consists of the addition of $7 \%$ sodium sulphate to the $3 \%$ sulphosalicylic acid. The second method consists of the use of a $3 \%$ trichloroacetic acid solution in water only. Both give good results comparable with the biuret and the Kafka methods for total protein in spinal fluids.

\section{REFERENCES}

1 M. J. Looney and A. J. Walsh, J. Biol. Chem., I 27 (I939) I I 7.

${ }^{2}$ G. Schneider, $Z$. physiol. Chem., Hoppe Seyler's, 283 (I948) II 2.

3 P. Cartier and J. PiCard, Ann. biol. clin. (Paris), 15 (I957) 459.

$4 \mathrm{~J}$. Booy, Colloq. St. Jans Hosp. Bruges, 4 (1956) 92.

5 J. B. Debro, H. Tarver and A. Korner, J. Lab. Clin. Med., 5o (1954) 728.

6 M. Delaville, G. Delaville and J. Delaville, Ann. biol. clin. (Paris), I2 (1954) 320. 